\title{
Environmental impact of an orchard winter wash and early season pesticide applications on both a beneficial and a pest mite species in Bramley apple orchards
}

\author{
${ }^{1 *}$ A. G. S. Cuthbertson and ${ }^{2}$ A. K. Murchie \\ ${ }^{1}$ Central Science Laboratory, Sand Hutton, York YO41 1LZ, UK \\ ${ }^{2}$ Department of Agriculture and Rural Development, Northern Ireland and the Queen's University of Belfast, Newforge \\ Lane, Belfast BT9 5PX, UK \\ Received 26 April 2006; revised 14 August 2006; accepted 1 September 2006; available online 1 October 2006

\begin{abstract}
Apple orchards often receive winter-washes to help aid invertebrate pest control. These can have detrimental environmental consequences. The application of winter-wash increased Aculus schlechtendali numbers while a decrease in numbers of the beneficial mite Anystis baccarum was observed. The application of early season pesticide treatments produced mixed results in relation to A. schlechtendali. Pirimiphos-methyl had no apparent detrimental effect on $A$. baccarum, whereas pirimicarb and phosalone reduced $A$. baccarum populations. The potential to incorporate an orchard winter-wash and early-season pesticide applications within integrated pest management strategies is discussed.
\end{abstract}

Key words: Winter wash, pesticide application, biological control, Bramley apple

\section{INTRODUCTION}

Apple orchards host many species of phytophagous arthropods that can inflict economic damage. Of these, the fruit tree red spider mite, Panonychus ulmi (Koch), (Acarina: Tetranychidae) and the apple rust mite, Aculus schlechtendali (Nalepa), (Acarina: Eriophyidae) rank among the most troublesome because of their persistence, the sudden and severe damage they can cause and their ability to develop resistance against pesticides (Gruys, 1982; Cuthbertson and Murchie, 2005a,b; 2006a). Many authors have attributed P. ulmi outbreaks to being man-made. For example, Massee (1929) found that the use of tar-distillate washes in early spring against the over-wintering stages of lepidopteran pests, led to outbreaks of P. ulmi. This was due to resurgence: the washes decimated natural enemy populations, which were unable to recover quickly enough to control the pests. Avoidance of resurgence of both target and non-target insect or mite species after pesticide treatment is important. Elimination of natural enemies is generally accepted as the main reason contributing to resurgence (McMurtry et al., 1970; van de Vrie et al., 1972; Croft and Brown,

\footnotetext{
*Corresponding author, Email: a.cuthbertson@csl.gov.uk Tel.: +440 1904 462201; Fax: +440 1904462111
}

1975; Cuthbertson et al., 2003a; Cuthbertson and Murchie, 2005b). In addition, the possible role of $A$. schlechtendali as an alternative food source for predatory mites in integrated pest management (IPM) programmes requires the use of selective pesticides (Wearing and Ashley, 1982; Easterbrook, 1984; Cuthbertson and Murchie, 2004a). Much research in England has shown that the predatory mite Typhlodromus pyri Scheuten is one of the most effective predators of P. ulmi and A. schlechtendali (Easterbrook, et al., 1985; Cross and Berrie, 1994). Typhlodromus pyri is capable of regulating P. ulmi at low non-damaging levels if the pesticide programme allows the predatory mite to survive (Easterbrook, 1984). Insecticides such as permethrin and pirimiphos-methyl kill T. pyri whilst others, such as diflubenzuron and pirimicarb, allow T. pyri to survive (Cranham and Solomon, 1981). However, within Northern Ireland's apple orchards the most abundant predatory mite is Anystis baccarum (Linnaeus) (Prostigmata: Anystidae), (Cuthbertson and Murchie, 2004b; Cuthbertson, 2005; Cuthbertson and Murchie, 2005c,d). Little work is published on the effects of spray chemicals on anystid mites. MacPhee and Sanford (1961), working on Anystis agilis (Banks), found that chemicals such as DDT, lead 
arsenate, malathion and parathion eliminated this mite, whereas kelthane had no detrimental effect. The only specific work on A. baccarum was by Bushkovskaya (1974) and Cuthbertson and Murchie (2006b) where the most toxic insecticides were determined to be dicofol, copper sulphate and phosalone. Cuthbertson and Murchie (2003) investigating the impact of chemical fungicide sprays on $A$. baccarum populations concluded that dithianon had a low toxicity to $A$. baccarum, whereas, mancozeb and captan/ penconazole had significant detrimental effects on $A$. baccarum population development. The aim of this study was to investigate the effects of early season sprays of three commonly-used pesticides in Northern Irish Bramley apple orchards on the beneficial mite $A$. baccarum, and its prey, $A$. schlechtendali. Also, in the same orchard the previous winter, a winter-wash was applied to half the orchard. Therefore, a further aim was to determine the effects of this spray on both predator and pest populations.

\section{MATERIALS AND METHODS}

Study orchard

The orchard used for this study was situated at the Northern Ireland Horticulture and Plant Breeding Station, Loughgall, County Armagh, UK (N 054 24.3' W $\left.006^{\circ} 35.8^{\prime}\right)$. This orchard had a tree density of 150/ha with an average tree height of $4 \mathrm{~m}$. The study was carried out over two growing seasons. The winter-wash was applied during February 1997 and then the pesticide trial was conducted during the apple growing season of 1998 within the same orchard.

\section{Treatments applied}

Winter-wash application

Half of the orchard received a tar oil winter wash. This was applied on 19 February 1997. The wash was tar oil (Mortegg emulsion, DowElanco, a mix of $45 \mathrm{l}$ product / $1000 \mathrm{l}$ water applied at a rate of $1200 \mathrm{l} / \mathrm{ha}$, active ingredient $60 \% \mathrm{w} / \mathrm{w}$ ).

\section{Pesticide treatments}

The treatments were [brand name, source, recommended dose rates, percentage active ingredient weight per weight]:

(1) Pirimicarb [Aphox, Zeneca, 560 g / 2001 water, 50\% w/w];

(2) Phosalone [Zolone Liquid, Hortichem, 2.1 l / 2001 water, 35\% w/w];
(3) Pirimiphos-methyl [Blex, Zeneca, 1.8 l/ 200 l water, $50 \% \mathrm{w} / \mathrm{w}]$

(4) Control - unsprayed.

Pesticide treatments were applied to individual trees via a hand-operated knap-sac sprayer at a rate of one litre per tree on the 23 April 1998 when the trees were at the green-cluster stage (Lyne, 1981). Treated trees were separated by guard trees to avoid cross-contamination by spray drift. The orchard received routine fungicide treatments throughout the season.

\section{Experimental design}

Both the winter wash and non-winter wash halves of the orchard were each divided into three randomised blocks with the four treatments per block.

\section{Aculus schlechtendali monitoring}

From 24 April until 25 August 1998, four leaves were taken at random from each tree at weekly intervals. These were washed in $30 \%$ ethanol and the number of $A$. schlechtendali present counted using a binocular microscope (Zacharda et al., 1988).

\section{Anystis baccarum monitoring}

Numbers of $A$. baccarum were recorded using a three-minute scan of trunk, lower branches and foliage of trees at weekly intervals (Cuthbertson et al., 2003a).

\section{Analysis of data}

Due to non replication of the winter-wash application, split-plot ANOVA was not appropriate. Therefore, each half of the orchard was analysed separately using ANOVA with post-ANOVA comparisons of means using the Least Significant Difference (LSD) test.

\section{RESULTS}

Although not analysed, the application of winter wash the previous winter almost certainly had an effect on both pest and predator. In the non-sprayed trees, in the winter-wash half, $A$. schlechtendali numbers peaked at $46.3( \pm 19.1)$ mites per four leaves $(n=3)$ compared to 18.6 ( \pm 14.2$)$ in the non winter-wash half (Figure 1a,b). Conversely, A. baccarum numbers peaked at $8.3( \pm 2.2)$ per three minute count per tree $(n=3)$ in the winter-wash half compared to $19.3( \pm 2.3)$ in the non winter-wash side (Figure 2a,b). There were no significant differences between pesticide treatments in the numbers of $A$. schlechtendali recorded in the 
non winter-wash side of the orchard (Fig. 1a). In the winter-wash half, on 13 August, there were more $A$. schlechtendali on the phosalone-treated leaves than on the other treatments $(F=6.42$, d.f. $=3,11, \mathrm{P}=0.02$; phosalone mean $=82.0$, control mean $=6.3, \mathrm{LSD}=45.7$ ) (Fig. 1b). Phosalone and pirimicarb treatments tended to have fewer A. baccarum in the winter-wash side of the orchard compared to the unsprayed control (Figure 2b). However, only on 30 May was this apparent difference significant to below the $5 \%$ level ( $F=6.35$, d.f $=3,11, \mathrm{P}=0.02$, phosalone mean $=2.6$, pirimicarb mean $=3.0$, pirimiphos-methyl mean $=5.3$, control mean = 7.6, LSD = 3.1). Pirimiphos-methyl appeared to have no detrimental effect on $A$. baccarum. There were no differences between pesticide treatments in the numbers of $A$. baccarum on trees in the non-winter wash half of the orchard (Fig. 2a).

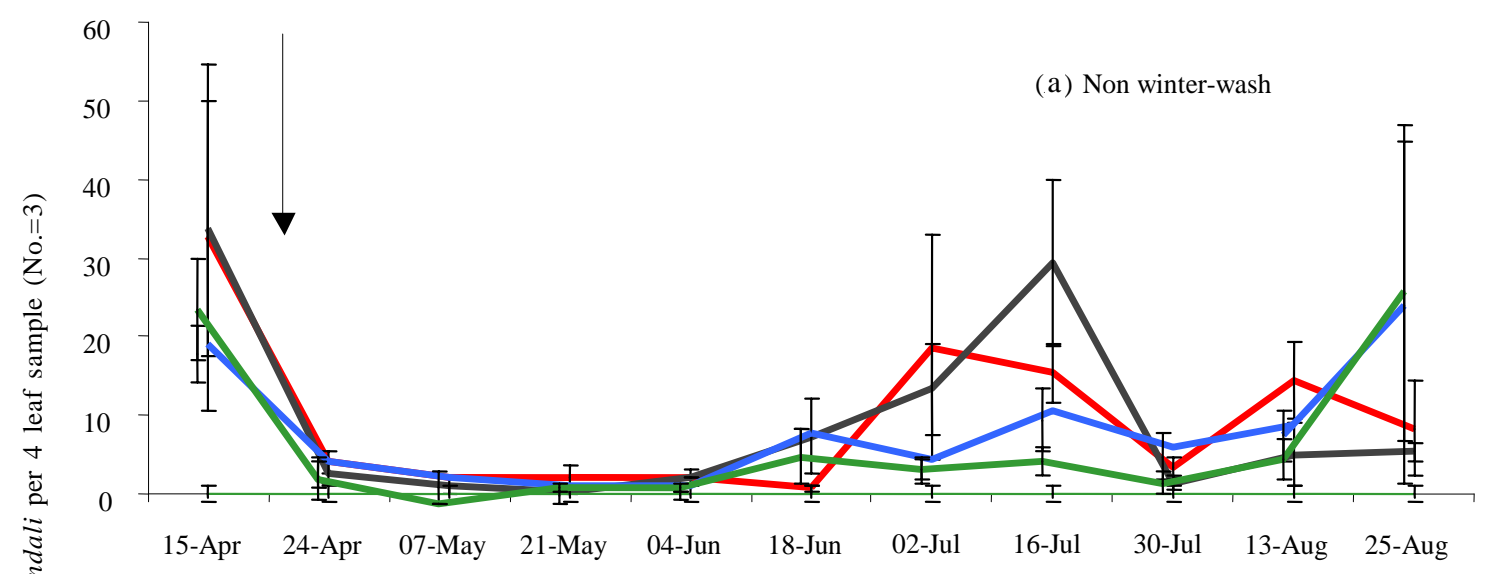

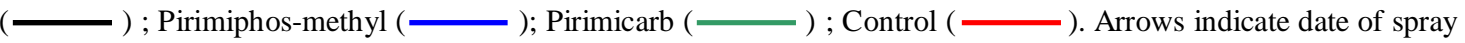

Fig. 1 a,b: Effect of a pre-blossom insecticide spray on Aculus schlechtendali in the Bramley orchard 1998. Phosalone application. Bars are standard error $( \pm)$ of the mean 


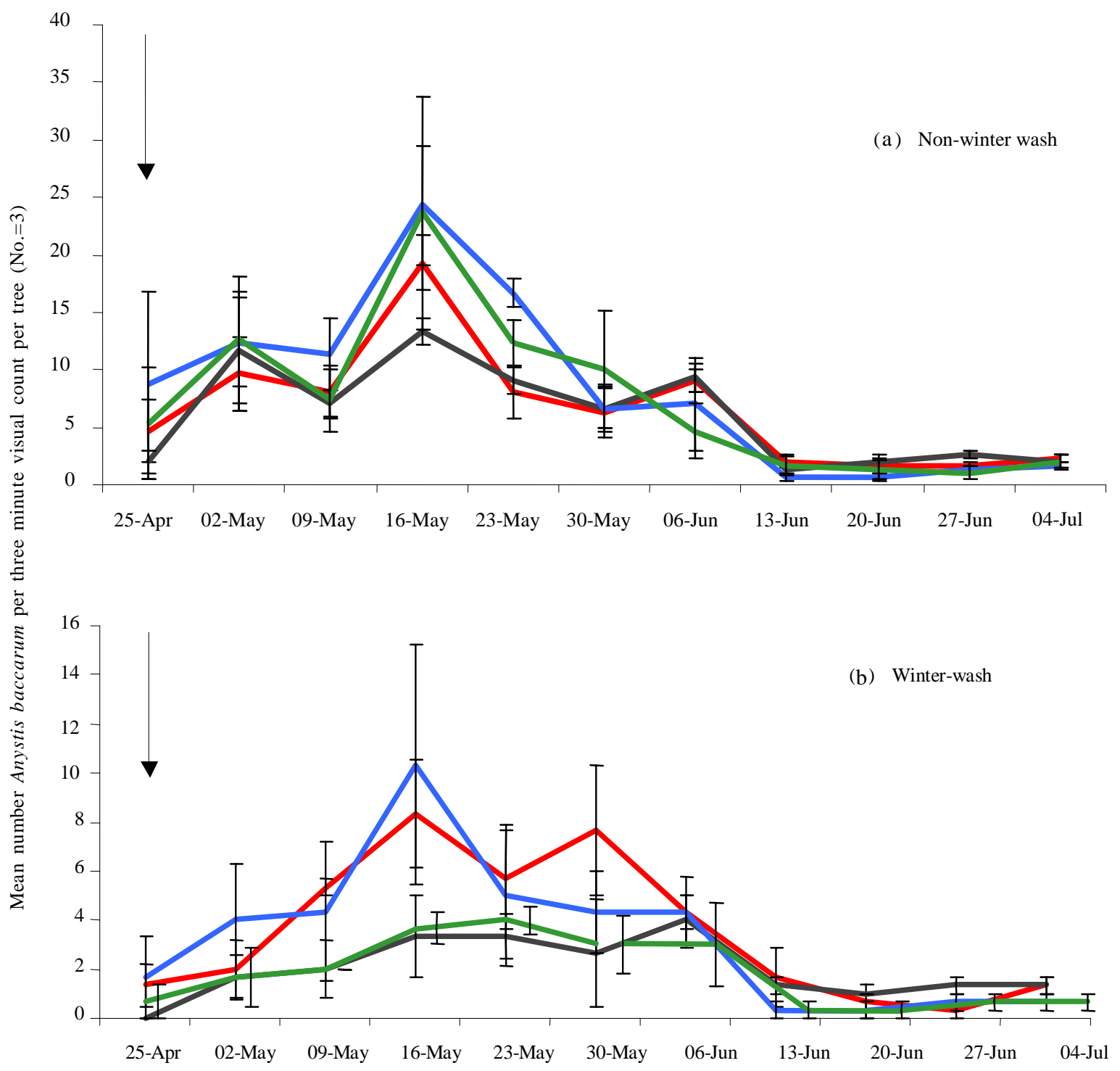

Fig. 2 a,b: Effect of a pre-blossom insecticide spray on Anystis baccarum in the Bramley orchard 1998. Phosalone

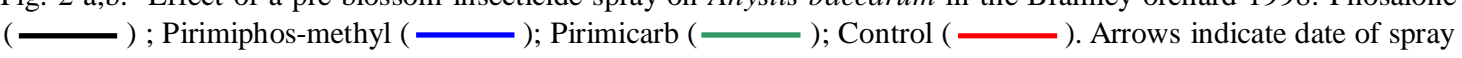
application. Bars are standard error $( \pm)$ of the mean

\section{DISCUSSION AND CONCLUSION}

Applications of winter washes are intended to control pests. However, they can also reduce natural enemy populations and, as a result, resurgence may occur (Hartfield and Campbell, 1996). Some winter washes are as effective as specific pesticides in lowering pest numbers. For example, an emulsified paraffin oil spray applied at bud burst/appearance of first leaves was highly effective against over-wintering eggs of P. ulmi (Nowakowski, 1982). In this present study, it would seem that the winter wash reduced predator numbers whilst a residual $A$. schlechtendali population remained and increased unchecked the following summer. In addition, the application of winter washes can aid fungal disease control in orchards; less scab infection and thus better leaf quality, may allow a 
greater A. schlechtendali infestation (Cuthbertson and Murchie, 2003). In the non-wash half of the orchard, more $A$. baccarum and presumably other predators such as T. pyri, could have led to smaller $A$. schlechtendali populations (Cuthbertson et al., 2003a). The pirimiphosmethyl application had little effect on $A$. schlechtendali, although it can rapidly reduce their populations when applied pre-blossom in dessert apples (Easterbrook, 1984). It is possible that the application in this study was too early, as it was applied at the green-cluster stage, at which time $A$. schlechtendali are still protected by being under buds. Pirimiphos-methyl had no apparent detrimental effect on $A$. baccarum which is surprising as it was found harmful to T. pyri (Easterbrook, 1984; Solomon et al., 1993; Cross and Berrie, 1996). The reasons for this are unclear but are unlikely to be due to spray date, given the apparent detrimental effects of phosalone and pirimicarb. Pirimiphos-methyl has a residual effect that may last for up to eight months on maize (White et al., 1997). As T. pyri is a leaf-dwelling predator, compared to $A$. baccarum which disperses more actively over the branches and foliage of trees (Cuthbertson, 2004; Cuthbertson and Murchie, 2004a), it would presumably have more contact with spray deposits. Differences in the toxicity of pesticides to A. baccarum and T. pyri are likely to be due to differences in size, habitat and behaviour. Body surface in contact with the spray deposit and the pattern of behaviour and speed of movement will determine the amount of pesticide picked up by an individual (Jepson et al., 1990). Also unexpected was the detrimental effect of pirimicarb on numbers of $A$. baccarum in the winter wash side. Such an effect was not found in the non-winter wash control. Again, the reasons for this difference are unclear. Pirimicarb, used mainly for aphid control, has a low toxicity towards T. pyri (Cranham and Solomon, 1981; Niemczyk, 1997). This spray may have indirectly affected $A$. baccarum by killing aphid prey. The applegrass aphid, Rhopalosiphum insertum (Walker) (Homoptera: Aphididae) is an important prey item for A. baccarum (Cuthbertson et al., 2003b), over-wintering populations would have already been reduced due to the winter wash and may have been eliminated completely by the pirimicarb spray. However, one would expect pirimiphos-methyl to have had the same effect, as it is also recommended for aphid control in orchards. Direct toxicity bioassays in the laboratory are needed to explain this anomaly.
Phosalone had a detrimental effect on $A$. baccarum in the winter wash half of the orchard. However, this insecticide has a lower toxicity to T. pyri than many other insecticides used in orchards (Karadzhov, 1973) and, as a result, has been used in IPM programmes (Niemczyk, 1997). There are conflicting reports about the effect of phosalone on pest species. Some authors have reported satisfactory control of $P$. ulmi using phosalone (Forsythe, 1970; Calabretta and TropeaGarzia, 1987), whilst others have found it ineffective (Pasqualini and Malavolta, 1985). However, in some situations a reduction in predatory species after phosalone application has increased pest problems (Hagley, 1979; Hislop and Prokopy, 1981). The main finding from this preliminary study is that although the application of a winter wash may reduce pest numbers immediately, in the long term it could increase them. The effect on natural enemies, especially $A$. baccarum, would appear to be detrimental. The predator was unable to recover quickly enough to prevent a resurgence in pest numbers. It would therefore be advisable to limit winter wash applications in the Bramley orchards. This would not only help preserve the natural enemy fauna but also other important non-target species such as honey bees (Apis mellifera) which are much needed within apple orchards for pollination purposes (Cuthbertson and Brown, 2006) and also prevent unnecessary environmental damage such as soil or water contamination. Thus, helping to encourage a more environmentally sustainable apple production system.

\section{ACKNOWLEDGEMENTS}

This study was carried out in conjunction with the Applied Plant Science Division, Department of Agriculture and Rural Development (DARD), Northern Ireland, research project number 9554. The authors also thank Mr. Sam Clawson and Mr. Peter McCorriston (DARD) for help in planning and carrying out the experiment and the staff of the Northern Ireland Horticulture and Plant Breeding Station, Loughgall, for applying the tar oil winter wash. Dr. Andrew G. S. Cuthbertson was funded by the Department of Agriculture and Rural Development (Northern Ireland) Studentship.

\section{REFERENCES}

Bushkovskaya, L. M., (1974). The effect of chemicals on the mite Anystis. Zashchita Rastenii, 10, 53. 
Calabretta, C. and Tropea-Garzia, G., (1987). Phosalone, in mixtures with acaricides, in a programme of supervised control of European red mite (Panonychus ulmi Koch) and codling moth (Cydia pomonella L.) on apple. Tecnica. Agricola., 39, 61-70.

Cranham, J. E. and Solomon, M. G., (1981). Mite management in commercial apple orchards. Report East Malling Research Station for 1980. 171-172.

Croft, B. A. and Brown, A. W. A., (1975). Responses of arthropod natural enemies to insecticides. Ann. Rev. Entomol., 20, 285-335.

Cross, J. V. and Berrie, A. M., (1994). Effects of repeated foliar sprays of insecticides or fungicides on organophosphate-resistant strains of the orchard predatory mite Typhlodromus pyri on apple. Crop. Prot., 13, 39-44.

Cross, J. V. and Berrie, A. M., (1996). Further field evaluation of the effects of repeated foliar sprays of insecticides or fungicides alone and in admixture on an organophosphateresistant strain of the orchard predatory mite. Typhlodromus pyri on apple. Crop. Prot., 15, 637-639.

Cuthbertson, A. G. S., (2004). Unnecessary pesticide applications in Northern Ireland apple orchards due to misidentification of a beneficial mite species. Res. J. Chem. Environ., 8 (3), 77-78.

Cuthbertson, A. G. S., (2005). Re-discovery of a predatory mite in Northern Irish apple orchards. Bio. News, 30, 29.

Cuthbertson, A. G. S. and Brown, M. A., (2006). Vital pollinators: honey bees in apple orchards. Biologist, 53, 7780

Cuthbertson, A. G. S. and Murchie, A. K., (2003). The impact of fungicides to control apple scab (Venturia inaequalis) on the predatory mite Anystis baccarum and its prey Aculus schlechtendali (apple rust mite) in Northern Ireland Bramley orchards. Crop Prot., 22, 1125-1130.

Cuthbertson, A. G. S. and Murchie, A. K., (2004a). The phenology, oviposition and feeding rate of Anystis baccarum, a predatory mite in Bramley apple orchards in Northern Ireland. Exper. Appl. Acarol., 34, 367-373.

Cuthbertson, A. G. S. and Murchie, A. K., (2004b). The presence of Anystis baccarum (L.) in Northern Ireland Bramley apple orchards. Ir. Nat. J., 27, 465-467.

Cuthbertson, A. G .S. and Murchie, A. K., (2005a). Economic spray thresholds in need of revision for Northern Irish Bramley orchards. Bio. News, 32, 19.

Cuthbertson, A. G. S. and Murchie, A. K., (2005b). European red spider mite - an environmental consequence of persistent chemical pesticide application. Int. J. Environ. Sci. Tech., 2 (3), 287-290.

Cuthbertson, A. G. S. and Murchie, A. K., (2005c). Techniques for environmental monitoring of predatory fauna on branches of Bramley apple trees in Northern Ireland. Int. J. Environ. Sci. Tech., 2 (1), 1-6.

Cuthbertson, A. G. S. and Murchie, A. K., (2005d). Environmental monitoring of Archips podana (fruit tree tortrix moth) in Bramley apple orchards in Northern Ireland. Int. J. Environ. Sci. Tech., 2 (2), 101-104.

Cuthbertson, A. G. S. and Murchie, A. K., (2006a). Environmental monitoring of economically important invertebrate pests in Bramley apple orchards in Northern Ireland. Int. J. Environ. Sci. Tech., 3 (1), 1-7.

Cuthbertson, A. G. S. and Murchie, A. K., (2006b). A preliminary study into the direct effect of chemical pesticides on the predatory mite Anystis baccarum. J. Ultra Sci. Physic. Sci., 18 (2), 177-180

Cuthbertson, A. G. S., Bell, A. C. and Murchie, A. K., (2003a). Impact of the predatory mite Anystis baccarum (Prostigmata: Anystidae) on apple rust mite Aculus schlechtendali (Prostigmata: Eriophyidae) populations in Northern Ireland Bramley orchards. Ann. Appl. Biol., 142, 107-114.

Cuthbertson, A. G. S., Fleming, C. C. and Murchie, A. K., (2003b). Detection of Rhopalosiphum insertum (apple-grass aphid) predation by the predatory mite Anystis baccarum using molecular gut analysis. Agri. For. Entomol., 5, 219-225.

Easterbrook, M. A., (1984). Effects of pesticides on the apple rust mite Aculus schlechtendali (Nal.) (Eriophyidae). J. Hort. Sci., 59, 51-55.

Easterbrook, M. A., Solomon, M. G., Cranham, J. E. and Souter, E.F., (1985). Trials of an integrated pest management programme based on selective pesticides in English apple orchards. Crop Prot., 4, 215-230.

Forsythe, H. Y., (1970). New insecticides for apples. Ohio Report, 55, 37-38.

Gruys, P., (1982). Hits and misses. The ecological approach to pest control in orchards. Entomol. Exper. Appl., 31, 70-87.

Hagley, E. A. C., (1979). Integrated pest management insecticides and natural predator populations on apple. Proc. Entomol. Soc. Ont., 109, 9-21.

Hartfield, C. M. and Campbell, C. A. M., (1996). The use of the selective insecticide pirimicarb for integrated pest management of plum aphids in UK orchards. Brighton Crop Protection Conference: Pests and Diseases, 3, 879-884.

Hislop, R. G. and Prokopy, R. J., (1981). Integrated management of phytophagous mites in Massachusetts (USA) apple orchards. II. Influence of pesticides on the predator Amblyseius fallacis (Acarina:Phytoseiidae) under laboratory and field conditions. Prot. Ecol., 3, 157-172.

Jepson, P. C., Chaudhry, A. G., Salt, D. W., Ford, M. G., Efe, E. and Chowdhury, A. B. N. M. U., (1990). A reductionist approach towards short-term hazard analysis for terrestrial invertebrates exposed to pesticides. Funct. Ecol., 4, 339348 .

Karadzhov, S., (1973). The problem of harmful Acarina on apple. Rastitelna Zashchita, 21, 21-26.

Lyne, P. M., (1981). Pirimiphos-methyl for rust mite control in UK orchards. Proc. Brit. Crop Prot. Confer. - Pests and Diseases, 1, 83-88.

MacPhee, A. W. and Sanford, K. H., (1961). The influence of spray programs on the fauna of apple orchards in Novia Scotia. XII. Second supplement to VII. Effects on beneficial arthropods. Can. Entomol., 93, 671-673.

Massee, A. M., (1929). The fruit tree red spider mite (Olygonychus ulmi C.L. Koch). Ann. Rep. East Mall. Res. St., 16, 116-122.

McMurtry, J. A., Huffaker, C. B. and van de Vrie, M., (1970). Tetranychid enemies: their biological characters and the impact of spray practices. Hilgardia, 40, 331-390.

Niemczyk, E., (1997). The occurrence of different groups of phytophagous and predatory mites on apple plots sprayed according to different programs. Zahradnictvi, 24, 45-52.

Nowakowski, Z., (1982). Control of the European red mite in early spring. Prace Instytutu Sadownictwa i Kwiaciarstwa w Skierniewicach A, 23, 123-130 (In Polish).

Pasqualini, E. and Malavolta, C., (1985). Possibility of natural 
limitation of Panonychus ulmi (Koch) (Acarina:Tetranychidae) on apple in Emilia-Romagna. Bollettino dell ' Istituto di Entomologia ' Guido Grandi ، della Universita degli Studi di Bologna, 39, 221-230.

Solomon, M.G., Easterbrook, M.A. and Fitzgerald, J.D., (1993). Mite management programmes based on organophosphateresistant Typhlodromus pyri in UK apple orchards. Crop Prot., 12, 249-254.

van de Vrie, M., McMurtry, J.A. and Huffaker, C.B., (1972). Ecology of tetranychid mites and their natural enemies: A review III. Biology, ecology and pest status, and host plant relations of tetranychids. Hilgardia, 41, 343-432.
Wearing, C.H. and Ashley, E., (1982). A recommended spray programme for integrated mite control on apples. Orch. NZ, 55, 27-29.

White, N.D.G., Jayas, D.S. and C.J. Demianyk, C.J., (1997). Degradation and biological impact of chlorpyrifos-methyl on stored wheat and pirimiphos-methyl on stored maize in western Canada. J. Stor. Prod. Res., 33, 125-135.

Zacharda, M., Pultar, O. and Muska, J., (1988). Washing technique for monitoring mites in apple orchards. Exper. Appl. Acarol., 5, 181-183.

\section{AUTHOR(S) BIOSKETCHES}

Cuthbertson, A. G. S., B.Sc., Ph.D., is an environmental entomologist at Central Science Laboratory in York, England, UK. He researches the development of integrated pest management strategies against both indigenous and non-indigenous invertebrate pest species.

Email: a.cuthbertson@csl.gov.uk

Murchie, A. K., B.Sc., Ph.D., is a senior scientific officer in the Department of Agriculture and Rural Development, Northern Ireland, UK. His research aims to establish the value of natural enemies in field pest control and evaluate the impact of invasive species on agri-ecosystems.

Email:archie.murchie@dardni.gov.uk

\section{This article should be referenced as follows:}

Cuthbertson, A. G. S. and Murchie, A. K., (2006). Environmental impact of an orchard winter wash and early season pesticide applications on both a beneficial and a pest mite species in Bramley apple orchards. Int. J. Environ. Sci. Tech., 3 (4), 333-339 